\title{
Media Kartu Permainan Berbasis Truth or Dare Play (TODP) pada Materi Virus
}

\section{Sagita Nea Rahmi1*, Relsas Yogica ${ }^{2}$}

1,2Jurusan Biologi, FMIPA, Universitas Negeri Padang

\section{ART I CLE INF O}

Article history:

Received August 04, 2021

Revised August 08, 2021

Accepted September 30, 2021

Available online October 25, 2021

Kata Kunci:

Pengembangan media, Kartu permainan Truth or Dare

Keywords:

Media Development, Truth or Dare Card Game

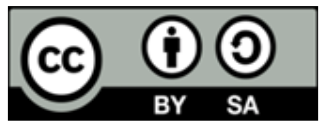

This is an open access article under the CC BY-SA license.

Copyright (ㅇ) 2021 by Author. Published by Universitas Pendidikan Ganesha.

\begin{abstract}
A B S T R A K
Media pembelajaran merupakan suatu perantara untuk menyampaikan pesan-pesan dalam pembelajaran. Hanya saja kenyataan di lapangan menunjukkan bahwa tidak semua guru mampu menyediakan media pembelajaran yang tepat. Tujuan penelitian ini untuk menghasilkan produk media kartu permainan berbasis TODP pada materi virus. Penelitian ini tergolong ke dalam jenis penelitian pengembangan, yang dikembangkan dengan menggunakan model IDI. Model pengembangan IDI terdiri dari tiga tahap yakni tahap pendefinisian, pengembangan, dan penilaian. Subjek yang terlibat dalam penelitian ini yakni 29 orang siswa SMA, 1 orang guru, serta 2 orang dosen yang berperan sebagai validator. Pengumpulan data dalam penelitian dilakukan dengan menggunakan metode observasi, wawancara, serta penyebaran angket. Instrumen yang digunakan yakni instrumen uji validitas media yang terdiri dari uji validitas isi, kebahasaan, penyajian, serta kegrafikan. Analisis validasi kartu Truth or Dare Play dilakukan dengan memberikan skor jawaban dengan empat alternatif jawaban yang disusun menurut skala Likert yang kemudian dianalisis dengan menggunakan rumus persentase. Hasil penelitian menunjukkan bahwa nilai rata-rata pengujian validitas media yakni $87,54 \%$ dengan kategori valid. Selanjutnya, pada hasil praktikalitas menunjukkan nilai rata-rata $92,35 \%$ untuk guru dengan kategori sangat praktis dan 93,83\% untuk peserta didik dengan kategori sangat praktis. Berdasarkan hasil tersebut dapat disimpulkan bahwa media kartu permainan berbasis Truth or Dare Play (TODP) pada materi virus valid serta layak untuk dikembangkan dan diimplemntasikan dalam pembelajaran karena mampu meningkatkan minat serta motivasi belajar peserta didik.
\end{abstract}

\begin{abstract}
A B S T R A C T
Learning media is an intermediary to convey messages in learning. It's just that the reality on the ground shows that not all teachers are able to provide the right learning media. The purpose of this research is to produce a TODP-based game card media product on virus material. This research belongs to the type of development research, which was developed using the IDI model. The IDI development model consists of three stages, namely the stages of defining, developing, and assessing. The subjects involved in this study were 29 high school students, 1 teacher, and 2 lecturers who acted as validators. Data collection in the study was carried out using the methods of observation, interviews, and distributing questionnaires. The instrument used is the media validity test instrument which consists of content validity, linguistic, presentation and graphic validity tests. The analysis of the validation of the Truth or Dare Play card was carried out by providing an answer score with four alternative answers arranged according to a Likert scale which was then analyzed using the percentage formula. The results showed that the average value of the media validity test was $87.54 \%$ with a valid category. Furthermore, the practicality results show an average value of $92.35 \%$ for teachers in the very practical category and $93.83 \%$ for students in the very practical category. So based on these results it can be concluded that the Truth or Dare Play based game card media on virus material is valid and feasible to be developed and taught to students, because it can increase students' interest and motivation to learn.
\end{abstract}




\section{PENDAHULUAN}

Mata pelajaran biologi merupakan salah satu mata pelajaran yang dibelajarkan kepada siswa pada jenjang Pendidikan Sekolah Menengah Atas (Afriyanti et al., 2021). Pada pembelajaran Biologi siswa dikenalkan terhadap berbagai makhluk hidup yang ada dan berkembang dalam diri manusia dalam lingkungan seperti virus, bakteri, dan jamur (Agnafia, 2019; Ariyanto et al., 2018; Jayawardana, 2017; Ummi, 2018). Materi virus menjadi salah satu materi yang banyak dibelajarkan pada siswa jenjang Pendidikan SMA. Virus merupakan salah satu materi yang bersifat abstrak yang tidak dapat diamati secara langsung dalam kehidupan sehari-hari (Darmawan \& Nawawi, 2020; Ramdhani et al., 2020). Dalam proses pembelajaran materi virus, siswa membutuhkan media pembelajaran yang dapat memvisualkan materi virus itu. Penggunaan media pembelajaran pada materi virus sangatlah dibutuhkan untuk meningkatkan pemahaman siswa (Kamiana et al., 2019; Putri, 2021). Media pada dasarnya merupakan salah satu komponen pembelajaran yang berfungsi untuk memvisualkan konsep abstak suatu materi ajar (Kuswanto \& Radiansah, 2018; Tafonao, 2018). Media juga dapat berperan sebagai perantara untuk menyampaikan pesan-pesan yang ada dalam pembelajaran (Karo-Karo \& Rohani, 2018; Nurrita, 2018). Proses pembelajaran yang memanfaatkan penggunaan media didalamnya akan dapat menarik minat serta motivasi belajar siswa (Dwiqi et al., 2020). Pemilihan media harus disesuaikan dengan karakteristik kebutuhan siswa, hal ini bertujuan agar media yang dibelajarkan dapat memenuhi fungsinya dengan baik (Thalib, 2021). Terdapat berbagai macam media yang dapat dimanfaat untuk proses pembelajaran seperti media cetak, media audio, maupun media audio visual. Dengan penggunaan media, guru akan lebih mudah untuk memaparkan materi kepada siswa serta siswa juga akan lebih mudah dalam memahami materi yang dibelajarkan (Istiqlal, 2018).

Pada pembelajaran biologi khususnya materi virus, variasi penggunaan media sangatlah dibutuhkan untuk menunjang proses pembelajaran. Hanya saja kenyataan di lapangan menunjukkan bahwa tidak semua guru mampu mengembangkan media yang sesuai dengan kebutuhan dan materi ajar. Hal ini sejalan dengan hasil observasi dan wawancara yang telah dilakukan di SMAN 2 Sungai Penuh. Hasil observasi menunjukkan bahwa penggunaan media dalam pembelajaran materi virus masih terbatas pada penggunaan Lembar Kerja Peserta Didik (LKPD) dan kadang-kadang menggunakan Power Point (PPT). Media pembelajaran yang seperti ini membuat peserta didik lebih cepat bosan, sehingga motivasi belajarnya rendah. Rendahnya motivasi belajar ditunjukkan dengan kurangnya partisipasi peserta didik dalam proses pembelajaran yang kemudian berdampak pada penurunan hasil belajar siswa. Jika hal ini dibiarkan secara terus menerus akan berdampak pula pada penurunan hasil belajar materi biologi lainnya.

Untuk mengatasi permasalahan tersebut, maka dibutuhkan media pembelajaran yang lebih efektif dan mampu meningkatkan motivasi belajar siswa. Salah satu media yang dapat digunakan yakni media kartu bermain berbasis truth or dare. Media kartu bermain truth or dare merupakan media yang di dalamnya berisi pertanyaan untuk dijawab dengan jujur dan berisi tantangan yang harus dilakukan secara berani (Tarigan \& Saskia, 2019; Vijayta \& Isnawati, 2022). Proses pembelajaran yang dilakukan dengan menggunakan media kartu truth or dare umumnya dilaksanakan secara berkelompok, dengan menggunakan dua macam kartu yakni kartu truth dan kartu dare (Fanny \& Sakti, 2021). Pada permainan truth or dare kartu truth umumnya berisi pertanyaan yang dijawab dengan jawaban "iya" atau "tidak", sedangkan kartu dare umumnya berisi tantangan yang harus dilakukan oleh siswa (Nasrudin \& Kurnadi, 2020). Konsep dari proses pembelajaran menggunakan media kartu bermain truth or dare yakni mengajak siswa untuk belajar sambil bermain. Dengan proses belajar sambil bermain, siswa akan lebih termotivasi untuk mengikuti proses pembelajaran serta materi pembelajaran akan dapat diterima dengan baik. Beberapa penelitian yang telah dilakukan sebelumnya mengungkapkan bahwa permainan truth or dare sangat layak digunakan dalam proses pembelajaran karena permainan ini dapat meningkatkan hasil belajar dan respon siswa dalam kegiatan belajar mengajar (Fanny \& Sakti, 2021). Penelitian lainnya juga mengungkapkan bahwa media kartu bermain truth or dare merupakan media yang sangat layak untuk dikembangkan dan dibelajarkan kepada peserta didik karena memiliki nilai valitas yang cukup tinggi (Rizqiyah, 2018). Penelitian selanjutnya juga mengungkapkan bahwa media pembelajan kartu bermain truth or dare praktis untuk digunakan dalam proses pembelajaran, sehingga layak untuk dikembangkan dan dibelajarkan kepada siswa (Vijayta \& Isnawati, 2022).

Berdasarkan beberapa hasil penilaian tersebut dapat dikatan bahwa media kartu bermain truth or dare merupakan media yang praktis untuk digunakan dalam proses pembelajaran. Selain itu, media ini juga dapat meningkatkan motivasi serta semangat belajar siswa. Hanya saja pada penelitian sebelumnya belum terdapat kajian mengenai penggembangan media pembelajaran truth or dare dalam pembelajaran materi virus siswa Sekolah Menengah Atas, sehingga penelitian ini difokuskan pada kajian tersebut dengan tujuan untuk untuk menghasilkan produk media kartu permainan berbasis TODP pada materi virus kelas X SMA. 


\section{METODE}

Penelitian Penelitian ini merupakan jenis penelitian pengembangan yang dikembangkan dengan menggunakan model Instructional Development Institute (IDI). Model pengembangan Instructional Development Institute (IDI) terdiri dari tiga tahapan yakni tahap pendefinisian (define), tahap pengembangan (develop), dan tahap penilaian (evaluate). Subjek yang terlibat dalam penelitian ini yakni 29 orang peserta didik kelas X SMAN 2 Sungai Penuh, 2 orang dosen Jurusan Biologi FMIPA UNP dan 1 orang guru biologi SMAN 2 Sungai Penuh. Pengumpulan data dalam penelitian dilakukan dengan menggunakan metode observasi, wawancara, serta angket. Adapun instrumen yang digunakan yakni instrumen uji validitas media yang terdiri dari uji validitas isi, kebahasaan, penyajian, serta kegrafikan. Analisis validasi kartu Truth or Dare Play dilakukan dengan memberikan skor jawaban dengan empat alternatif jawaban yang disusun menurut skala Likert, yang kemudian dianalisis dengan menggunakan rumus persentase.

\section{HASIL DAN PEMBAHASAN}

Hasil

Pengembangan media kartu pembelajaran truth or dare dilakukan dalam tiga tahapan pengembangan. Adapun hasil dari tiap-tiap tahap pengembangan adalah sebagai berikut: tahap pengembangan yang pertama yakni tahap pendefinisian (define). Tahap ini dilakukan dengan melakukan analisis pada kurikulum yang digunakan, analisis terhadap media pembelajaran, analisis peserta didik, serta analisis konsep. Adapun hasil analisis kurikulum menunjukkan bahwa sebanyak $57,2 \%$ peserta didik mengatakan materi virus sulit. Pernyataan tersebut didukung oleh sebagian besar alasan peserta didik memilih kesulitan dalam memahami materi virus karena materinya rumit dan banyak istilah-istilah yang membingungkan. Selanjutnya, pada hasil analisis media pembelajaran ditemukan bahwa dalam proses pembelajaran, guru lebih banyak menggunakan media berupa LKPD dan Power Point. Saat proses pembelajaran, peserta didik merasa bosan dan kurang tertarik untuk mempelajari mata pelajaran biologi. Di samping itu, pembelajaran masih belum maksimal dilakukan karena masih terdapat peserta didik yang tidak berpartisipasi aktif pada saat pembelajaran biologi.

Analisis ketiga yakni analisis terhadap peserta didik untuk mengetahui kebutuhan media pembelajaran yang sesuai dengan peserta didik. Hasil analisis menunjukkan bahwa peserta didik cenderung belajar dengan cara membaca. Hal ini terjadi karena kegiatan ini kurang ditunjang oleh media pembelajaran, yaitu dengan menyediakan media pembelajaran yang menarik minat belajar peserta didik yang membuatnya menjadi aktif. Untuk itu, peserta didik membutuhkan media pembelajaran lain atau tambahan dalam memahami materi virus. Berdasarkan angket yang diberikan kepada peserta didik, didapatkan sebanyak 83,6\% setuju menggunakan metode bermain berupa kartu permainan berbasis TODP. Selanjutnya, pada hasil analisis konsep detemukan bahwa siswa kesulitan untuk memahami materi virus. Setelah hasil analisis kebutuhan siswa dilakukan, maka penelitian dilanjutkan pada tahap kedua, yakni pengembangan media (develop). Pada tahap ini dilakukan proses perancangan produk dan pengujian validitas produk. Perancangan produk media dilakukan dengan menentukan KD, Indikator, tujuan pembelajaran, merancang soal-soal, serta merancang media kartu bermain. Hasil dari proses perancangan produk, yakni diputuskan bahwa materi yang disajikan dalam media yakni materi virus dengan soal yang digunakan pada kartu yaitu soal salah benar dan pilihan ganda. Peserta didik yang bisa menjawab soal salah benar akan mendapatkan 10 point, sedangkan jika peserta didik dapat menjawab pertanyaan dari soal pilihan ganda, maka akan mendapatkan 15 point. Media kartu bermain truth or dare dirancang dengan menggunakan CorelDRAW X7 dan bahan yang digunakan untuk mencetak kartu adalah kertas A karton 260. Media kartu berbasis TODP ini memiliki 2 jenis kartu soal yang berbeda yaitu: Kartu Truth yang berisikan soal salah benar dengan warna kartu yaitu warna biru dengan jumlah kartu 20, serta kartu dare yang berisi soal pilihan ganda dengan warna kartu yaitu warna ungu dengan jumlah kartu 20.

Media pembelajaran yang telah dikembangkan kemudian diuji validitasnya oleh validator yaitu dua orang dosen biologi di Jurusan Biologi FMIPA UNP dan satu orang guru biologi di SMAN 2 Sungai penuh dengan menggunakan angket validasi. Pada tahap validasi terdapat masukan dan saran dari validator yang menjadi acuan atau dasar pertimbangan untuk melakukan revisi pada media kartu permainan berbasis TODP pada materi virus. Sesuai dengan saran dari para validator, dilakukan revisi pada media kartu permainan berbasis TODP pada materi virus. Setelah dilakukan revisi media kartu permainan berbasis TODP, selanjutnya validator memberikan penilaian validitas yaitu pada aspek kelayakan isi, kebahasaan, penyajian, dan kegrafikaan. Hasil validasi dari beberapa validator dapat dilihat pada Tabel 1. 
Tabel 1. Hasil uji validitas media kartu permainan baerbasis TODP pada materi virus Kelas

\begin{tabular}{ccc}
\hline Aspek Penilaian & Nilai Validitas & Kategori \\
\hline Kelayakan Isi & $84,72 \%$ & Valid \\
Kebahasaan & $83,33 \%$ & Valid \\
Penyajian & $91,66 \%$ & Sangat Valid \\
Kegrafikaan & $90,47 \%$ & Sangat Valid \\
Total & $350,18 \%$ & \\
Rata-rata & $87,54 \%$ & Valid \\
\hline
\end{tabular}

Berdasarkan pada tabel 1 dapat diketahui bahwa rata-rata hasil validitas media yakni sebesar $87,54 \%$ dengan kategori valid. Hal ini menunjukkan bahwa media kartu permainan berbasis TODP pada materi virus yang dikembangkan telah valid baik dari aspek kelayakan isi, komponen kebahasaan, komponen penyajian dan komponen kegrafikaan sehingga dapat digunakan dalam pembelajaran. Media kartu permainan berbasis TODP pada materi virus yang telah valid diujicobakan untuk uji praktikalitas kepada guru dan peserta didik di SMAN 2 Sungai Penuh pada tahap penilaian.

Tahap ketiga dalam proses pengembangan media yakni tahap penilaian (evaluate). Tahap penilaian (Evaluate) dilakukan dengan melakukan uji praktikalitas untuk mengetahui tingkat kepraktisan media kartu permainan berbasis TODP pada materi virus yang digunakan dalam proses pembelajaran. Uji praktikalitas dilakukan terhadap satu guru dan 35 orang peserta didik kelas X SMAN 2 Sungai Penuh. Hasil penilaian uji praktikalitas oleh guru dan peserta didik dapat dilihat pada Tabel 2 .

Tabel 2. Hasil Penilaian Uji Praktikalitas oleh Guru

\begin{tabular}{ccc}
\hline Aspek Penilaian & Guru & Hasil dan Keterangan \\
Peserta Didik \\
\hline Kemudahan Penggunaan & $91,66 \%$ (Sangat Praktis) & $96,37 \%$ (Sangat Praktis) \\
Daya tarik & $93,75 \%$ (Sangat Praktis) & $93,75 \%$ (Sangat Praktis) \\
Manfaat Penggunaan & $91,66 \%$ (Sangat Praktis) & $91,37 \%$ (Sangat Praktis) \\
Rata-rata Nilai Praktikalitas & $92,35 \%$ (Sangat Praktis) & $93,83 \%$ (Sangat Praktis) \\
\hline
\end{tabular}

Hasil uji praktikalitas media kartu permainan berbasis TODP pada materi virus pada Tabel 2 menunjukkan rata-rata sebesar 92,35\% dengan kategori sangat praktis oleh guru dan 93,83\% dengan kategori sangat praktis oleh peserta didik. Hal ini menunjukkan bahwa media kartu permainan berbasis TODP pada materi virus yang dikembangkan telah praktis baik dari aspek kemudahan penggunaan, daya tarik, dan manfaat penggunaan, sehingga dapat digunakan dalam pembelajaran.

\section{Pembahasan}

Berdasarkan hasil analisis data didapatkan hasil bahwa media katu bermain berbasis truth or dare berada dalam kategori valid, sehingga sangat layak untuk dikembangkan. Kelayakan penggunaan media kartu bermain berbasis truth or dare disebabkan oleh beberapa faktor sebagai berikut. Faktor pendukung keberhasilan yang pertama, yakni media pembelajaran kartu bermain truth or dare telah sesuai dengan kebutuhan siswa serta karakteristik siswa. Kebutuhan siswa pada pembelajaran materi virus yakni siswa membutuhkan bahan ajar yang mampu meningkatkan pemahaman serta hapalan siswa (Nisak, 2021). Hal ini sangat sesuai dengan karakteristik kartu permainan truth or dare yang mengajak siswa untuk memahami suatu materi dengan menggunakan kartu yang berisi daftar pertanyaan (Renatha \& Rosdiana, 2020; Restian et al., 2020). Selain sesuai dengan kebutuhan siswa, kartu bermain juga sesuai dengan karakteristik siswa Sekolah Menengah Atas. Siswa sekolah menengah atas merupakan siswa yang berada pada usia remaja dan dalam proses pembelajarannya siswa cenderung mudah bosan dan kurang tertarik pada proses pembelajaran yang terkesan menoton (Budiningsih, 2017). Proses pembelajaran dengan menggunakan media kartu bermain truth or dare memberikan pengalaman baru pada siswa serta membantu siswa dalam memahami materi melalui kegiatan bermain truth or dare (Dony et al., 2019; Harnadia et al., 2021).

Faktor keberhasilan kedua, yakni media yang dikembangkan memiliki keterbacaan yang jelas, sesuai dengan KI, KD, kebutuhan peserta didik, kebenaran isi, dan kesesuaian kurikulum yang berlaku sesuai dengan kriteria. Pada hakikatnya, pembuatan media pembelajaran harus sesuai dengan kompetensi dasar yang didasarkan pada kurikulum yang berlaku (Surata et al., 2020). Hal ini bertujuan agar informasi yang disampaikan bisa dimengerti dan dipahami oleh peserta didik. Selain telah sesuai dengan KI dan KD, 
media kartu bermain truth or dare yang dikembangkan memiliki aspek kebahasaan yang baik. Aspek kebahasaan berkaitan dengan pengunaan Bahasa yang sesuai dengan kaidah penulisan yang baik dan benar serta memiliki susunan kalimat yang tepat dan jelas (Puspita, 2019). Penggunaan bahasa dalam sebuah media akan dikatakan baik apabila memiliki kejelasan informasi, sesuai dengan kaidah bahasa indonesia yang baik dan benar, menggunakan bahasa yang jelas dan singkat, serta sesuai dengan tingkat perkembangan peserta didik. Dalam sebuah media, bahasa menjadi salah satu komponen utama yang menentukan keberhasilan sebuah media. Melalui bahasa, peserta didik akan lebih mudah memahami materi yang terdapat pada media pembelajaran yang digunakan.

Faktor ketiga, yakni media yang dikembangkan memiliki unsur kegrafikan yang menarik. Unsur kegrafikan berkaitan dengan desain tampilan, font, tata letak, ilustrasi, gambar. Media dengan unsur kegrafikan yang menarik tentunya akan menarik minat siswa untuk mempelajari serta mengamatinya (Darmawan \& Nawawi, 2020). Selain itu, penggunakan font, tata letak, dan gambar yang sesuai juga akan membantu siswa untuk memahami isi kartu tesebut (Ummah, 2021). Font merupakan aspek yang berkaitan dengan jenis, ukuran, serta warna huruf yang digunakan. Penggunaan ukuran, warna, serta jenis huruf yang tepat akan dapat memudahkan siswa dalam membaca teks yang disajikan.

Faktor keempat, yakni media yang dikembangkan praktis untuk digunakan. Kemudahan kepraktisan dalam penggunaan media merupakan salah satu aspek yang dinilai dalam kepraktisan suatu produk (Kumalasani, 2018). Dalam proses pembelajaran, media pembelajaran yang mudah digunakan sangat berpengaruh yang akan membuat peserta didik senang dan termotivasi untuk belajar. Pada saat pembelajaran, daya tarik sangat dibutuhkan oleh peserta didik agar dapat menarik perhatian dan minat peserta didik ke dalam proses pembelajaran. Tingginya tingkat ketertarikan peserta didik juga dapat didukung oleh terlihatnya suasana aktif pada saat uji coba berlangsung. Peserta didik juga terlihat senang dan tidak sabar menunggu giliran untuk bermain.

Hasil yang diperoleh pada penelitian ini sejalan dengan hasil penelitian terdahulu yang juga mengungkapkan bahwa permainan truth or dare sangat layak digunakan dalam proses pembelajaran, karena permainan ini dapat meningkatkan hasil belajar dan respon siswa dalam kegiatan belajar mengajar (Fanny \& Sakti, 2021). Penelitian lainnya juga mengungkapkan bahwa media kartu bermain truth or dare merupakan media yang sangat layak untuk dikembangkan dan dibelajarkan kepada peserta didik karena memiliki nilai valitas yang cukup tinggi (Rizqiyah, 2018). Penelitian selanjutnya juga mengungkapkan bahwa media pembelajan kartu bermain truth or dare praktis untuk digunakan dalam proses pembelajaran sehingga layak untuk dikembangkan dan dibelajarkan kepada siswa (Vijayta \& Isnawati, 2022). Hal ini menunjukkan bahwa media kartu bermain sangat layak digunakan dalam berbagai proses pembelajaran karena mampu meningkatkan aktivitas, motivasi, serta hasil belajar peserta didik.

\section{SIMPULAN}

Simpulan yang dapat ditarik dari hasil penelitian ini yakni media kartu permainan berbasis Truth or Dare Play (TODP) pada materi virus valid serta layak untuk dikembangkan dan dibelajarkan kepada siswa karena mampu meningkatkan minat serta motivasi belajar peserta didik.

\section{DAFTAR RUJUKAN}

Afriyanti, E., Japa, I. G. N., \& Renda, N. T. (2021). Hubungan Kebiasaan Belajar dengan Hasil Belajar IPA Siswa. Jurnal Pedagogi Dan Pembelajaran, 4(2), 338. https://doi.org/10.23887/jp2.v4i2.35188.

Agnafia, D. N. (2019). Analisis Kemampuan Berpikir Kritis Siswa dalam Pembelajaran Biologi. Florea: Jurnal Biologi Dan Pembelajarannya, 6(1), 45. https://doi.org/10.25273/florea.v6i1.4369.

Ariyanto, A., Priyayi, D. F., \& Dewi, L. (2018). Penggunaan Media Pembelajaran Biologi di Sekolah Menengah Atas (SMA) Swasta Salatiga. Jurnal Pendidikan Biologi, 9(1), 1. https://doi.org/10.24127/bioedukasi.v9i1.1377.

Budiningsih, C. A. (2017). Karakteristik Siswa sebagai Pijakan dalam Penelitian dan Metode Pembelajaran. Jurnal Cakrawala Pendidikan, 1(1). https://doi.org/10.21831/cp.v1i1.4198.

Darmawan, H., \& Nawawi, N. (2020). Pengembangan Media Pembelajaran Interaktif dan Lembar Kerja Siswa pada Materi Virus. JPBIO (Jurnal Pendidikan Biologi), 5(1), 27-36. https://doi.org/10.31932/jpbio.v5i1.573.

Dony, N., Mashuri, M. T., \& Nuriah, N. (2019). Perbandingan Media Kartu Pintar dan Truth and Dare terhadap Hasil Belajar Materi Larutan Penyangga di SMAN 1 Alalak. PSEJ (Pancasakti Science Education Journal), 4(2), 115-120. https://doi.org/10.24905/psej.v4i2.10.

Dwiqi, G. C. S., Sudatha, I. G. W., \& Sukmana, A. I. W. I. Y. (2020). Pengembangan Multimedia Pembelajaran 
Interaktif Mata Pelajaran IPA untuk Siswa SD Kelas V. Jurnal Edutech Undiksha, 8(2), 33. https://doi.org/10.23887/jeu.v8i2.28934.

Fanny, C. D. A., \& Sakti, N. C. (2021). Pengembangan Media Pembelajaran Permainan Truth and Dare untuk Meningkatkan Hasil Belajar Siswa. Jurnal Ilmiah Pendidikan Ekonomi Fakultas Keguruan Dan Ilmu Pendidikan, 9(2), 353-355. https://doi.org/10.33603/ejpe.v9i2.5074.

Harnadia, R., Eguweleira, S. H., Rumantyo, I. F. D., Himmah, A. C. A., Misbachussudur, M., Hanafi, M. A., \& Dewi, E. S. (2021). Increasing Confidence for The Blind with Braile Dare or Truth Card Games in Muhammadiyah School of Difable Jombang. Caring Jurnal Pengabdian Masyarakat, 1(2), 9-15. https://doi.org/10.21776/ub.caringjpm.2021.001.02.2.

Istiqlal, A. (2018). Manfaat Media Pembelajaran dalam Proses. Jurnal Kepemimpinan Dan Pengurusan Sekolah, 3(2), 139-144. https: //core.ac.uk/download/pdf/230524657.pdf.

Jayawardana, H. B. A. (2017). Paradigma Pembelajaran Biologi di Era Digital. Jurnal Bioedukatika, $5(1), 12$. https://doi.org/10.26555/bioedukatika.v5i1.5628.

Kamiana, A., Kesiman, M. W. A., \& Pradnyana, G. A. (2019). Pengembangan Augmented Reality Book sebagai Media Pembelajaran Virus Berbasis Android. Kumpulan Artikel Mahasiswa Pendidikan Teknik Informatika (KARMAPATI), 8(2), 165. https://doi.org/10.23887/karmapati.v8i2.18351.

Karo-Karo, I. R., \& Rohani, R. (2018). Manfaat Media dalam Pembelajaran. Axiom : Jurnal Pendidikan Dan Matematika, 7(1). https://doi.org/10.30821/axiom.v7i1.1778.

Kumalasani, M. P. (2018). Kepraktisan Penggunaan Multimedia Interaktif pada Pembelajaran Tematik Kelas IV SD. Jurnal Bidang Pendidikan Dasar, 2(1A), 1-11. https: //doi.org/10.21067/jbpd.v2i1A.2345.

Kuswanto, J., \& Radiansah, F. (2018). Media Pembelajaran Berbasis Android pada Mata Pelajaran Sistem Operasi Jaringan Kelas XI. Jurnal Media Infotama, 14(1). https://doi.org/10.37676/jmi.v14i1.467.

Nasrudin, K., \& Kurnadi, D. (2020). Pengembangan Media Pembelajaran Permainan Truth and Dare Kelas V SDS Muhammadiyah 3 Al-Hilal Tarakan. Judiksa Borneo, 2(1). http://180.250.193.171/index.php/judikdas/article/view/1562.

Nisak, N. Z. (2021). Analisis Kebutuhan Bahan Ajar Biologi untuk Siswa SMA Ditinjau dari Tingkat Kesulitan Materi, Keterampilan Berpikir Tingkat Tinggi, dan Keaktifan Belajar Siswa. EduBiologia: Biological Science and Education Journal, 128. https://doi.org/10.30998/edubiologia.v1i2.9629.

Nurrita, T. (2018). Pengembangan Media Pembelajaran untuk Meningkatkan Hasil Belajar Siswa. Misykat: Jurnal Ilmu-Ilmu Al-Quran, Hadist, Syari'ah Dan Tarbiyah, 3(1), 171. https://doi.org/10.33511/misykat.v3n1.171.

Puspita, L. (2019). Pengembangan Modul Berbasis Keterampilan Proses Sains sebagai Bahan Ajar dalam Pembelajaran Biologi. Jurnal Inovasi Pendidikan IPA, 5(1), 79-88. https://doi.org/10.21831/jipi.v5i1.22530.

Putri, N. (2021). Pengembangan Media Pembelajaran Video Berbasis Microsoft Office Powerpoint pada Materi Virus Kelas X SMA / MA. Jurnal Pendidikan Tambusai, 5(2), 6847-6855. https://doi.org/10.31004/jptam.v5i3.2033.

Ramdhani, S. I., Magfirah, N., \& Hambali, H. (2020). Pengaruh Penggunaan Media Komik terhadap Hasil Belajar Siswa pada Materi Virus Kelas X Di SMA Negeri 2 Gowa. Binomial, 3(1), 15-25. https://doi.org/10.46918/binomial.v3i1.480.

Renatha, G. T. B., \& Rosdiana, L. (2020). Validitas Permainan Kartu Truth and Dare Materi Pencemaran Lingkungan untuk Siswa SMP Kelas VII. Pensa E-Jurnal: Pendidikan Sains, 8(2), 138-145. https://ejournal.unesa.ac.id/index.php/pensa/article/view/38362.

Restian, A., Muzakki, A., \& Purnamasari, W. I. (2020). Model Pembelajaran Talking Stick melalui Permainan Truth or Dare pada Tari Bungong Jeumpa Kelas IV Sekolah Dasar. Satwika: Kajian Ilmu Budaya Dan Perubahan Sosial, 4(1), 1-9. https://doi.org/10.22219/satwika.v4i1.11435.

Rizqiyah, N. . (2018). Pengembangan Media Pembelajaran Permainan Truth or Dare untuk Meningkatkan Hasil Belajara Siswa Kelas X IPS SMA Khadijah Surabaya. JUPE, 6(3), 277 - 281. https://doi.org/10.26740/jupe.v6n3.p\%25p.

Surata, I. K., Sudiana, I. M., \& Sudirgayasa, I. G. (2020). Meta-Analisis Media Pembelajaran pada Pembelajaran Biologi. Journal of Education Technology, 4(1), 22. https://doi.org/10.23887/jet.v4i1.24079.

Tafonao, T. (2018). Peranan Media Pembelajaran dalam Meningkatkan Minat Belajar Mahasiswa. Jurnal Komunikasi Pendidikan, 2(2), 103. https://doi.org/10.32585/jkp.v2i2.113.

Tarigan, D., \& Saskia, E. (2019). Pengaruh Media Permainan Truth or Dare ( TOD ) terhadap Hasil Belajar Matematika Siswa di Kelas V SDN 107399 Bandar Khalipah. Seminar Nasional Pendidikan Dasar Universitas Negeri Medan, 84-95. 
https://jurnal.unimed.ac.id/2012/index.php/snpu/article/view/16111/12566.

Thalib, A. S. (2021). Pengembangan Media Bimbingan Konseling Permainan Monopoli Truth and Dare untuk Meningkatkan Self Confidence pada Peserta Didik. Indonesian Journal of School Counseling: Theory, Application, and Development, 1(1), 21. https://doi.org/10.26858/ijosc.v1i1.19319.

Ummah, K. (2021). Pengembangan Modul Pembelajaran Biologi Berbasis Reading, Questioning, and Answering (RQA) Materi Virus Kelas X. Jurnal Biologi Dan Pembelajarannya (JB\&P), 8(1), 19-25. https://doi.org/10.29407/jbp.v8i1.15264.

Ummi, A. (2018). Pengembangan Media Pembelajaran Biologi Semester II Kelas X SMA Berbasis Lectora Inspire. Jurnal Nalar Pendidikan, 6(1), 41. https://doi.org/10.26858/jnp.v6i1.6041.

Vijayta, E. S., \& Isnawati. (2022). Profil dan Validitas Media Permainan Truth or Dare Berbasis TGT untuk Melatih Keterampilan Berpikir Kritis Siswa pada Materi Sistem Sirkulasi Kelas XI. Jurnal Ilmiah Pendidikan Biologi, 11(1),

68-76. https://ejournal.unesa.ac.id/index.php/bioedu/article/view/39955/36325. 